\title{
Analisis Prioritas Solusi Permasalahan Pengelolaan Wakaf Produktif (Studi Kasus Kabupaten Banjarnegara)
}

\section{Analysis of Problems' Solutions Priority in Managing Productive Waqf (Case Study of Banjarnegara District)}

\author{
Resfa Fitri $^{1}$, Heni P Wilantoro ${ }^{2}$
}

${ }^{1}$ Departemen Ilmu Ekonomi Syariah, Fakultas Ekonomi dan Manajeman IPB 16680, email: rfitri2@ gmail.com

${ }^{2}$ Departemen Ilmu Ekonomi Syariah, Fakultas Ekonomi dan Manajeman IPB 16680, email: wilantoro1996@gmail.com

\begin{abstract}
Waqf is one of the instruments in Islamic economics that can be used for development funding. In addition, waqf is also very potential to improve people's welfare. In essence, the waqf is a matter that should be productively managed as contained in the hadith. However, it is currently in the opposite state. This study analyzes the priority of problems and solutions to optimize the management of waqf assets in Banjarnegara Regency, one of regencies in Central Java with highest poverty rate. Analytic Network Process (ANP) is the method used in this study. The result of the research shows that the main priority of human resource problem is the low managerial ability of the nazhir. The priority of institutional problem is the role of BWI Banjarnegara that is not yet optimal, while the priority of the government problem is the lack of support and role of the government. The priority solution of the most important problem is coaching and mentoring for nazhir.
\end{abstract}

Keywords: ANP, Islamic economics, productive waqf, waqf management

\begin{abstract}
Abstrak. Wakaf merupakan salah satu instrumen dalam ekonomi syariah yang dapat digunakan untuk pendanaan pembangunan. Selain itu, wakaf juga sangat berpotensi untuk meningkatkan kesejahteraan masyarakat. Pada hakikatnya wakaf merupakan suatu hal yang harus diproduktifkan sebagaimana yang terdapat dalam hadis. Namun, saat ini wakaf belum banyak yang dikelola secara produktif. Penelitian ini menganalisis permasalahan wakaf produktif dan solusinya di Kabupaten Banjarnegara, yang merupakan salah satu kabupaten di Jawa Tengah dengan angka kemiskinan tertinggi. Metode yang digunakan dalam penelitian ini adalah Analytic Network Process (ANP). Hasil penelitian menunjukkan bahwa prioritas utama masalah sumber daya manusia adalah kemampuan manajerial nazhir masih rendah. Masalah kelembagaan yang menjadi prioritas utama adalah peran BWI Kabupaten Banjarnegara belum optimal. Prioritas masalah pemerintah, yaitu kurangnya dukungan dan peran pemerintah. Prioritas solusi dari masalah yang paling penting adalah pembinaan dan pendampingan nazhir.
\end{abstract}

Kata Kunci: ANP, ekonomi syariah, manajemen wakaf, wakaf produktif

\section{PENDAHULUAN}

Kemiskinan saat ini sudah menjadi masalah multidimensi karena berkaitan dengan ketidakmampuan akses secara ekonomi, sosial budaya, politik, dan partisipasi dalam masyarakat. Kemiskinan merupakan masalah yang dihadapi oleh setiap negara. Negara Indonesia memiliki jumlah penduduk pada tahun 2017 sekitar 261 juta jiwa dengan jumlah penduduk miskin sekitar 26.58 juta penduduk atau $10.12 \%$ dari total jumlah penduduk Indonesia (BPS, 2018). Jumlah ini turun sebesar $0.52 \%$ dari tahun sebelumnya.

Indonesia merupakan negara yang memiliki populasi penduduk beragama Islam terbesar di dunia. Data BPS (2010) mencatat 87.18\% dari populasi penduduk indonesia atau 207176162 jiwa yang beragama Islam. Selain populasi muslim yang sangat besar, Indonesia juga memiliki luas tanah wakaf yang paling luas di dunia. Saat ini tanah wakaf di Indonesia yang tercatat mencapai 4952525000 meter persegi dengan jumlah 335300 lokasi, dimana 121046 belum memiliki sertifikat wakaf dan 214254 sudah memiliki sertifikat wakaf (SIWAK, 2018). Luas ini hampir enam kali luas Singapura. Dengan populasi penduduk muslim yang sangat banyak dan luas tanah wakaf yang sangat luas, wakaf 
di Indonesia memiliki potensi yang sangat besar sebagai instrumen pembangunan dan penanggulangan kemiskinan.

Wakaf merupakan salah satu instrumen dalam ekonomi syariah yang sangat potensial untuk meningkatkan kesejahteraan masyarakat dan mengatasi masalah kemiskinan. Wakaf memiliki dua sisi hubungan, yakni hubungan kepada Allah dalam bentuk ibadah dan juga sisi hubungan kepada manusia dalam bentuk muamalah. Wakaf memiliki fungsi sosial yang dapat memberikan maslahah yang sangat besar untuk masyarakat, baik muslim maupun non muslim, jika dapat dikelola secara produktif dan optimal.

Dalam sejarah Islam, wakaf sudah dikenal sejak masa Rasulullah shallallahu'alaihi wa sallam. Syariat wakaf diturunkan setelah Nabi Muhammad berhijrah ke Kota Madinah, yakni pada tahun ke-2 hijriyah. Pada saat itu wakaf sudah dikelola secara produktif seperti tanah wakaf di daerah Khaibar yang diwakafkan oleh Umar bin Khattab radiyallahu 'anhu.

Wakaf dapat memiliki kontribusi terhadap pembangunan ekonomi suatu negara, yaitu dapat mengurangi pengeluaran pemerintah, meratakan distribusi pendapatan, mengurangi kemiskinan, dan dapat meningkatkan pertumbuhan ekonomi. Akan tetapi, saat ini potensi wakaf tersebut belum dimanfaatkan secara optimal di Indonesia. Sebagian besar peruntukan wakaf di Indonesia kurang mengarah pada pemberdayaan ekonomi umat dan cenderung pada kegiatan ibadah yang lazim, seperti untuk masjid, mushalla, sekolah, madrasah, pondok pesantren, dan makam (Sa'adah \& Wahyudi, 2016). Saifuddin et al. (2014) juga menyatakan bahwa peran wakaf dalam sosial ekonomi menurun signifikan dikarenakan opini masyarakat tersebut.

Berdasarkan data yang diperoleh dari Kementerian Agama RI menunjukkan bahwa pengelolaan tanah wakaf di Indonesia masih kurang mengarah kepada pemberdayaan ekonomi karena kebanyakan wakaf tanah tersebut sebagian besar masih berupa wakaf langsung (konsumtif). Hal itu dapat dilihat di Gambar 1 yang menunjukkan penggunaan tanah wakaf masih didominasi untuk masjid (44.92\%), mushalla (28.50\%), makam (4.62\%), sekolah (10.52\%), pesantren (3.12\%), dan sosial lainnya (8.33\%) (SIWAK, 2018). Menurut Djunaedi dan Almuin (2013), fenomena ini disebabkan oleh beberapa faktor di antaranya pemahaman keagamaan yang tradisional, kebutuhan rumah ibadah, milik keluarga, milik yayasan, responden masyarakat yang menyatakan bahwa wakaf yang berorientasi profit dapat menimbulkan konflik dan perpecahan sehingga mengganggu kekhusyukan ibadah.

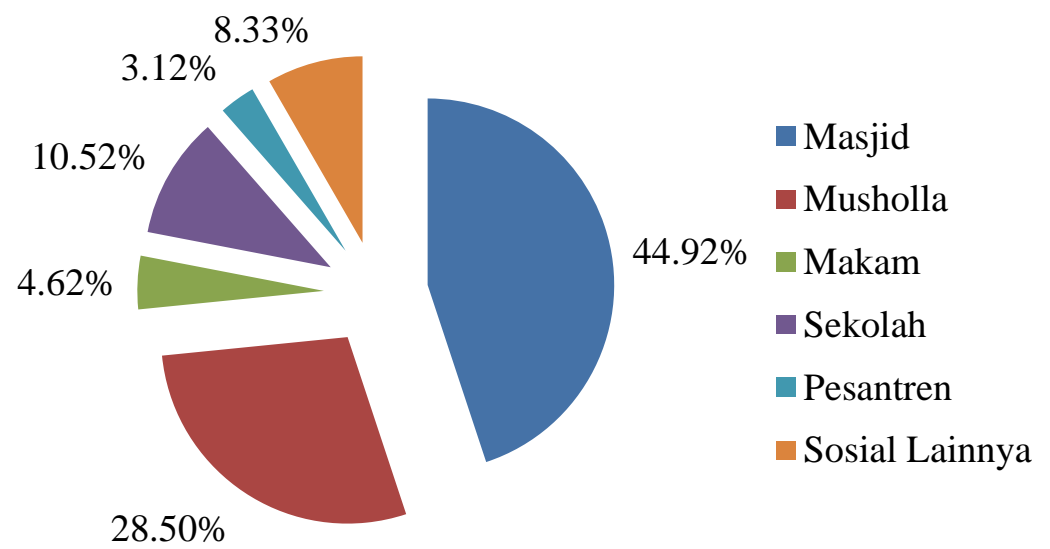

Sumber: Sistem Informasi Wakaf Kementerian Agama RI (2018)

Gambar 1 Penggunaan tanah wakaf di Indonesia

Pemanfaatan wakaf saat ini kebanyakan dilihat dari segi sosialnya saja sehingga kurang berpengaruh positif terhadap ekonomi masyarakat. Padahal pemerintah telah mendukung untuk memproduktifkan wakaf dengan mengeluarkan UU Nomor 41 Tahun 2004 tentang Wakaf dan juga PP RI Nomor 42 
Tahun 2006 tentang Pelaksanaan UU Nomor 41 Tahun 2004 tentang Wakaf. Akan tetapi sejak dikeluarkan regulasi tersebut sampai sekarang belum ada perkembangan yang signifikan terhadap pengelolaan wakaf ke arah yang produktif yang dapat mengembangkan ekonomi masyarakat.

Kabupaten Banjarnegara yang terletak di Provinsi Jawa Tengah merupakan salah satu kabupaten yang memiliki angka kemiskinan yang tinggi. Data dari BPS mencatat ada sekitar $17.27 \%$ atau sekitar 156 800 penduduk miskin di Kabupaten Banjarnegara, dari total penduduk 912917 jiwa (BPS, 2017). Menurut penelitian yang dilakukan Nurwati (2008) menyebutkan ada lima faktor yang berkorelasi dengan kemiskinan, yaitu pendidikan, jenis pekerjaan, gender, dan akses terhadap layanan dasar dan infrastruktur, serta lokasi geografis.

Potensi aset tanah wakaf Kabupaten Banjarnegara belum dimanfaatkan secara optimal ke arah yang produktif. Berdasarkan data dari Kementerian Agama Kabupaten Banjarnegara tahun 2015, wakaf yang produktif masih sangat kecil, yakni sebanyak 12 lokasi dari total 3723 lokasi atau sekitar $0.30 \%$ dari jumlah total tanah wakaf. Hal tersebut menunjukkan tingkat pengelolaan wakaf di Kabupaten Banjarnegara belum sampai pada tahap pengelolaan yang produktif.

Padahal pemerintah telah mendorong untuk memproduktifkan aset-aset wakaf dengan mengeluarkan UU Nomor 41 Tahun 2004 tentang Wakaf dan juga Peraturan Pemerintah RI Nomor 42 Tahun 2006 tentang Pelaksanaan UU Nomor 41 Tahun 2004 tentang Wakaf, yang di dalamnya mengatur masalahmasalah baru, seperti pengelolaan harta benda wakaf harus produktif dan peruntukannya dirinci secara jelas, di antaranya membantu fakir miskin, pembentukan Badan Wakaf Indonesia, peraturan wakaf uang, dan permasalahan-permasalahan lainnya.

Jika aset wakaf yang ada tersebut dikelola secara produktif akan menjadi aset bagi umat yang mampu memberikan manfaat yang banyak, di antaranya membantu fakir msikin, kaum dhuafa, dan lain sebagainya. Pada hakikatnya wakaf merupakan suatu hal yang harus diproduktifkan yang menghasilkan nilai ekonomi, sebagaimana sabda Nabi shalallahu 'alaihi wa salam kepada Umar, "Bila engkau suka, kau tahan (pokoknya) tanah itu dan engkau sedekahkan (hasilnya)" (HR. Muslim). Namun, pada kenyataannya wakaf belum banyak yang dikelola secara produktif untuk pemberdayaan ekonomi. Berdasarkan uraian tersebut, maka tujuan penelitian ini adalah sebagai berikut:

1 Menganalisis prioritas permasalahan pengelolaan wakaf di Kabupaten Banjarnegara.

2 Menganalisis prioritas solusi dari pemasalahan pengelolaan wakaf di Kabupaten Banjarnegara.

\section{TINJAUAN PUSTAKA}

\section{Definisi Wakaf}

Kata wakaf berasal dari bahasa arab, yaitu waqafa yang artinya berhenti, berdiri, dan mencegah (Kamus Al-Munawir). Menurut syariat, wakaf adalah menahan harta yang mungkin bisa dimanfaatkan namun zat barangnya tetap utuh, dengan memastikan penggunaan barangnya pada perkara yang mubah (Al-Mubarakfury, 2016). Dalam definisi lain, para ulama ahli fiqih saling berbeda pendapat dalam mendefinisikan wakaf. Imam Ahmad bin Hambal dan Imam Asy Syafi'i berpendapat bahwa wakaf adalah melepaskan harta yang diwakafkan dari kepemilikan wakif, setelah sempurna prosedur perwakafan, wakif tidak boleh melakukan apa saja terhadap harta yang diwakafkan seperti perlakuan pemilik dengan cara pemiliknya kepada yang lain, baik tukar-menukar atau tidak (Kemenag, 2006). Menurut pasal 1 Undang-Undang Nomor 41 Tahun 2004 menjelaskan bahwa definisi wakaf adalah perbuatan hukum wakif untuk memisahkan dan/atau menyerahkan sebagian harta benda miliknya untuk dimanfaatkan selamanya atau untuk jangka waktu tertentu sesuai dengan kepentingannya guna keperluan ibadah dan atau kesejahteraan umum menurut syariah. 


\section{Dasar Hukum Wakaf}

Di antara dalil disyariatkannya wakaf adalah sebagai berikut:

1 Al-Quran

Dalam Al-Quran secara umum tidak terdapat ayat yang menerangkan konsep wakaf secara jelas. Oleh karena wakaf termasuk infak di jalan Allah, maka yang menjadi dasar wakaf adalah ayat-ayat tentang infak di jalan Allah. Ayat-ayat tersebut, antara lain:

Allah subhanahu wa ta'ala berfirman,

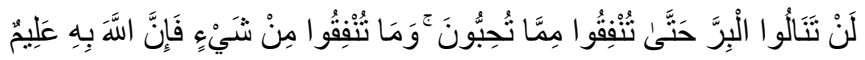
"Kamu sekali-kali tidak sampai kepada kebajikan (yang sempurna) sebelum kamu menafkahkan sebagian dari apa yang kamu cintai." (Q.S. Ali Imran (3): 92).

Dan juga Firman Allah ta'ala,

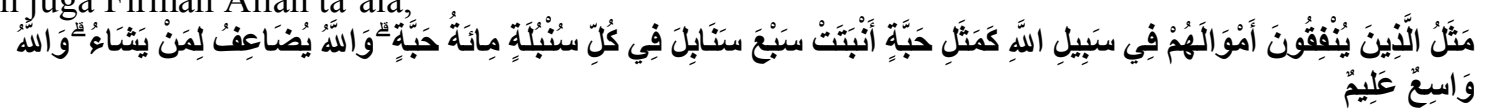

"Perumpamaan (nafkah yang dikeluarkan oleh) orang-orang yang menafkahkan hartanya di jalan Allah adalah serupa dengan sebutir benih yang menumbuhkan tujuh bulir. Pada tiap-tiap bulir seratus biji. Allah melipat gandakan (ganjaran) bagi sesiapa yang Dia kehendaki, dan Allah Maha Luas (karunia-Nya) lagi Mahamengetahui.” (Q.S. Al-Baqarah (2): 261).

Ayat-ayat tersebut di atas menjelaskan tentang anjuran untuk menginfakkan harta yang diperoleh untuk mendapatkan pahala dan kebaikan. Di samping itu, ayat 261 surat Al-Baqarah telah menyebutkan pahala yang berlipat ganda yang akan diperoleh orang yang menginfakkan hartanya di jalan Allah.

2 Hadis Nabi Muhammad shallallahu 'alaihi wa sallam

Diriwayatkan dari Ibnu Umar Radyiallahu 'anhu,ia berkata, "Umar radiyallahu 'anhu mendapat jatah sebidang tanah di Khaibar kemudian ia menghadap Nabi shalallahu 'alaihi wa sallam untuk meminta pendapat beliau. Umar berkata, "Wahai Rasulullah, aku mendapatkan jatah tanah di Khaibar dan aku belum pernah mendapatkan harta yang lebih berharga daripada tanah tersebut.". Beliau bersabda, "Jika kamu mau, kamu boleh wakafkan tanahnya dan menyedekahkan hasilnya.". Maka Umar pun menyedekahkan hasilnya dengan syarat tanahnya tidak boleh dijual, tidak diwariskan, dan tidak pula dihibahkan. Adapun hasilnya ia sedekahkan kepada fakir miskin,fi sabilillah,kepada ibnu sabil, dan tamu. Adapun oeang yang mengelola tanah tersebut tidak mengapa memakan hasilnya sesuai dengan kebutuhan dan memberi makan kepada teman dengan syarat tidak menyimpannya. (Muttafaq 'alaihi. Lafazh ini tercantum dalam riwayat Muslim).

Imam At Tirmidzi berkata; "pengamalan hadis ini menurut para ulama dari kalangan sahabat Rasulullah shallallahu 'alaihi wa sallam, kami tidak mengetahui di antara seorang pun di antara para penghulu tersebut ada perbedaan pendapat dalam hal ini. Ini merupakan wakaf pertama dalam Islam” (Al-Mubarrakfury, 2016).

\section{Macam-macam wakaf}

Bila ditinjau dari produktivitas wakaf, maka wakaf dapat dibagi menjadi dua macam (Kemenag, 2006), yaitu:

1 Wakaf produktif, yaitu wakaf yang dikelola untuk kegiatan produktif dan hasilnya dimanfaatkan untuk kepentingan umum. Yakni wakaf yang dikelola untuk kegiatan yang produktif yang menghasilkan nilai ekonomi yang kemudian hasilnya diberikan sesuai dengan tujuan wakaf, seperti wakaf untuk pertanian, perikanan, perkebunan, ruko, dan lain sebagainya.

2 Wakaf konsumtif, yaitu wakaf yang tidak dipergunakan untuk aktivitas yang produktif. Yakni wakaf yang pokok barangnya langsung digunakan sesuai dengan tujuan wakaf, seperti wakaf yang diperuntukan untuk masjid, untuk sekolah, dan lain sebagainya. 
Pasal 16 UU Nomor 41 Tahun 2004 membagi harta jenis wakaf menjadi dua macam, yaitu:

1 Benda tidak bergerak, yaitu meliputi hak atas tanah, bangunan, atau bagian bangunan yang berdiri di atas tanah, tanaman, atau benda lain yang terkait dengan tanah dan benda tidak begerak lainya yang sesuai dengan ketentuan syariah.

2 Benda bergerak, yaitu meliputi uang, logam mulia, surat-surat berharga, hak atas kekayaan intelektual, kendaraan, hak sewa, dan benda bergerak lainnya yang sesuai dengan ketentuan syariah.

\section{Rukun dan Syarat Wakaf}

Wakaf dinyatakan sah apabila telah terpenuhi rukun dan syaratnya. Rukun wakaf ada empat (Kemenag, 2006),yaitu:

1 Wakif (orang yang mewakafkan harta), seorang wakif disyaratkan harus memiliki kecakapan hukum, ada empat kriteria seorang dikatakan memiliki cakap hukum, yaitu merdeka, berakal sehat, dewasa (sudah baligh), dan tidak berada di bawah pengampuan (boros atau lalai)

2 Mauquf bih (barang atau harta yang diwakafkan)

3 Mauquf 'alaih (pihak yang diberi wakaf atau peruntukan wakaf)

4 Shighat (pernyataan atau ikrar wakif sebagai suatu kehendak untuk mewakafkan sebagai harta bendanya)

\section{Penelitian Terdahulu}

Yuliani (2017) melakukan penelitian tentang strategi optimalisasi pengelolaan wakaf di Indonesia dengan menggunakan metode Analytic Network Process (ANP). Penelitian ini meneliti masalah, solusi, dan strategi dalam optimalisasi pengelolaan wakaf. Masalah yang menyebabkan pengelolaan wakaf di Indonesia belum optimal terbagi menjadi dua, yaitu masalah internal dan eksternal. Masalah internal menjadi prioritas utama yang menyebabkan pengelolaan wakaf di Indonesia belum optimal. Penelitian ini juga menyajikan solusi untuk mengoptimalkan pengelolaan wakaf agar menjadi lebih produktif. Solusi juga terbagi manjadi dua aspek, yaitu solusi internal dan solusi eksternal. Solusi internal menjadi prioritas utama untuk mengoptimalkan pengelolaan wakaf agar menjadi lebih produktif. Strategi yang dirumuskan berdasarkan masalah dan solusi dibagi menjadi tiga, yaitu sinergi dan kolaborasi antarlembaga, sosialisasi dan edukasi secara komprehensif kepada semua elemen, serta optimalisasi sumber daya yang sudah ada. Strategi sosialisasi dan edukasi secara komprehensif kepada semua elemen menjadi proritas utama dalam penelitian ini.

Hamzah (2016) melakukan penelitian tentang analisis faktor-faktor yang memengaruhi pengelolaan wakaf di Kabupaten Bogor. Penelitian ini menggunakan metode Analytic Network Process (ANP). Faktor-faktor yang dapat memengaruhi pengelolaan wakaf di Kabupaten Bogor dalam penelitian ini terbagi menjadi empat aspek, yaitu aspek sumber daya manusia, aspek lembaga, aspek pemerintah, dan aspek geografis. Aspek sumber daya manusia memiliki pengaruh yang paling besar dibandingkan dengan aspek-aspek yang lain.

Khadijah (2016) melakukan penelitian tentang faktor-faktor yang memengaruhi tingkat penghimpunan wakaf uang di Indonesia dengan menggunakan metode Analytic Network Process (ANP). Dalam penelitian ini faktor-faktor yang memengaruhi tingkat penghimpunan wakaf uang terbagi menjadi tiga aspek, yaitu aspek kelembagaan, aspek pemerintahan, dan aspek masyarakat. Aspek kelembagaan memiliki prioritas utama yang mempengaruhi penghimpunan wakaf uang di Indonesia, kemudian aspek masyarakat dan aspek pemerintah.

Huda (2015) melakukan penelitian tentang prioritas solusi permasalahan wakaf di Provinsi Jawa Barat dengan metode Analytic Network Process (ANP). Dalam penelitian ini terdapat tiga macam prioritas masalah dan solusi wakaf yang dibagi berdasarkan pemangku kepentingan wakaf, yaitu regulator, pengelola wakaf (nazhir), serta wakif. Aspek paling bermasalah dalam pengelolaan wakaf di Jawa Barat adalah aspek nazhir. Permasalahan nazhir yang paling utama adalah nazhir bukan sebagai profesi utama. Prioritas permasalahan wakif adalah wakif tidak koordinasi dengan ahli waris dan 
prioritas masalah regulator adalah biaya APBN untuk sertifikasi wakaf. Untuk prioritas solusi terhadap masalah nazhir bukan sebagai profesi utama adalah transformasi nazhir individu menjadi lembaga. Prioritas solusi aspek wakif di Jawa Barat dengan masalah wakif tidak koordinasi dengan ahli waris adalah penyerahan wakaf dibuatkan berita acara. Prioritas solusi aspek regulator dengan masalah biaya APBN untuk sertifikasi wakaf di Jawa Barat adalah penggunaan APBD untuk tiap wilayah.

Saifuddin et al. (2014) mengemukakan tiga isu dalam implementasi wakaf di Malaysia, antara lain klarifikasi tentang pengembangan wakaf berdasarkan opini akademisi Islam, hambatan legislasi, dan masalah administrasi baitul mal yang tidak efisien dan tidak sistematis. Kurangnya SDM menjadi salah satu faktor penyebab terbesar. Selain itu, regulasi yang tersedia pun berbeda-beda di seluruh negara bagian dan tidak komprehensif, hanya aspek manajerial dan prosedur singkat saja.

Perbedaan penelitian ini dengan penelitian terdahulu adalah penelitian ini dilakukan dengan menggunakan metode Analytic Network Process (ANP) untuk mengidentifikasi dan menganalisis solusi dari permasalahan pengelolaan wakaf produktif di Kabupaten Banjarnegara agar menjadi lebih produktif dan optimal. Dalam penelitian ini terdapat tiga aspek masalah dan solusi, yaitu aspek sumber daya manusia, kelembagaan, dan pemerintah.

\section{METODE}

\section{Waktu dan Lokasi Penelitian}

Penelitian ini dilaksanakan pada bulan Maret hingga April 2018 di Kabupaten Banjarnegara. Pengambilan data dilakukan melalui wawancara para pakar di bidang wakaf, di antaranya nazhir wakaf, Majelis Ulama Indonesia (MUI), Badan Wakaf Indonesia (BWI), dan Kementerian Agama Kabupaten Banjarnegara.

\section{Jenis dan Sumber Data}

Berdasarkan jenisnya, penelitian ini menggunakan data primer dan sekunder. Data primer diperoleh dari hasil observasi lapangan, yaitu dengan wawancara para pakar di bidang wakaf. Data sekunder diperoleh dari jurnal ilmiah serta dari berbagai sumber, seperti Badan Pusat Statistik (BPS), Kementerian Agama Kabupaten Banjarnegara, Badan Wakaf Indonesia (BWI), dan pihak-pihak lain yang relevan.

\section{Metode Pengambilan Responden}

Pengambilan responden berdasarkan non probability sampling dimana pengumpulan informasi dan pengetahuan dari pakar menggunakan metode purposive sampling untuk menentukan pakar yang akan dilibatkan dalam penelitian. Metode purposive sampling adalah metode pengambilan sampel yang dilakukan berdasarkan pertimbangan tentang beberapa karakteristik yang cocok berkaitan dengan anggota sampel yang diperlukan untuk menjawab tujuan penelitian. Pertimbangan-pertimbangan yang digunakan untuk menentukan pakar adalah kesesuaian pendidikan pakar, pengalaman pakar, jabatan pakar, dan track record kepakarannya. Jumlah sampel dalam penelitian ini terdiri dari lima orang pakar wakaf. Dalam metode ANP kecukupan jumlah data tidak menjadi syarat, yang penting adalah bahwa data diambil dari responden yang menguasai/ahli dalam masalah tersebut (Ascarya, 2005).

\section{Metode Analisis Data}

Analisis data dalam penelitian ini menggunakan metode Analytic Network Process (ANP). Metode ANP merupakan pengembangan dari metode AHP. ANP mengizinkan adanya interaksi dan umpan balik dari elemen-elemen dalam cluster (inner dependence) dan antar-cluster (outer dependence) (Rusydiana \& Devi, 2013). Metode ini digunakan dalam penyelesaian permasalahan yang kompleks dan diperlukan adanya prioritas dalam pengambilan keputusannya. Dalam penelitian ini software yang digunakan untuk analisis data adalah SuperDecision dan Microsoft Excel. 


\section{Gambaran umum metode Analytic Network Process (ANP)}

Metode ANP berfungsi untuk menangani permasalahan yang kompleks, yaitu dengan cara menstruktur kompleksitas secara hierarkis ke dalam cluster-cluster yang homogen dari faktor-faktor. Metode ini digunakan dalam bentuk penyelesaian dengan pertimbangan atas penyesuaian kompleksitas masalah secara penguraian sintesis disertai adanya skala prioritas yang menghasilkan pengaruh yang terbesar. Pengambilan keputusan dalam aplikasi metode ANP adalah dengan melakukan pertimbangan dan validasi atas pengalaman empiris.

\section{Landasan ANP}

ANP memiliki empat aksioma yang menjadi landasan teori (Rusydiana \& Devi, 2013), yaitu:

1 Resiprokal; aksioma ini menyatakan bahwa jika PC (EA,EB) adalah nilai pembandingan pasangan dari elemen $\mathrm{A}$ dan $\mathrm{B}$, dilihat dari elemen induknya $\mathrm{C}$, yang menunjukkan berapa kali lebih banyak elemen A memiliki apa yang dimiliki elemen B, maka PC $(E B, E A)=1 / \mathrm{Pc}$ (EA,EB). Misalkan, jika A lima kali lebih besar dari B, maka B besarnya 1/5 dari besar A.

2 Homogenitas; menyatakan bahwa elemen-elemen yang dibandingkan dalam struktur kerangka ANP sebaiknya tidak memiliki perbedaan terlalu besar, yang dapat menyebabkan lebih besarnya kesalahan dalam menentukan penilaian elemen pendukung yang memengaruhi keputusan.

3 Prioritas; yaitu pembobotan secara absolut dengan menggunakan skala interval [0.1] dan sebagai ukuran dominasi relatif.

4 Dependence condition; diasumsikan bahwa susunan dapat dikomposisikan ke dalam komponen-komponen yang membentuk bagian berupa cluster.

\section{Tahapan penelitian}

Metode ANP memiliki tahapan sebagai berikut:

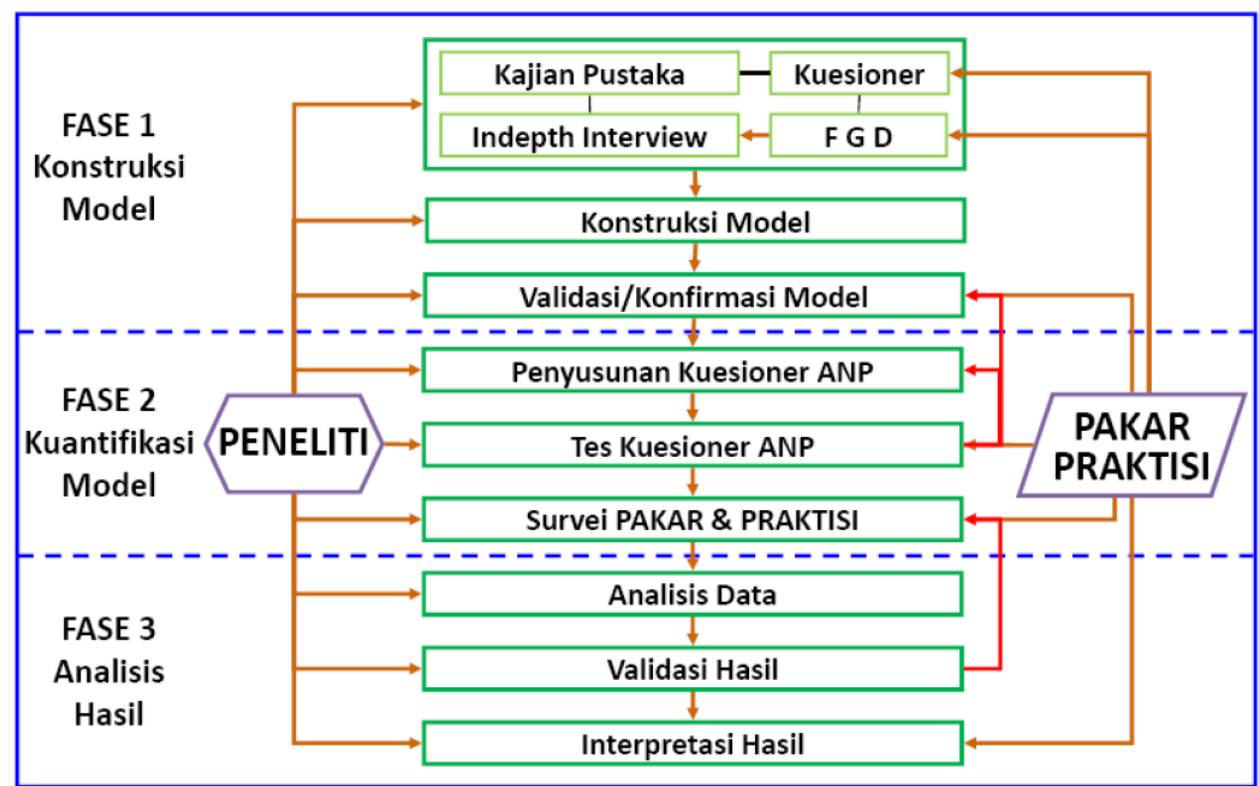

Sumber: Ascarya dan Yumanita (2011)

Gambar 2 Tahapan dalam metode ANP

1 Konstruksi Model

Konstruksi model ANP disusun berdasarkan literature review secara teori maupun empiris dan melakukan indepth interview dengan melakukan wawancara kepada para pakar wakaf untuk mengkaji informasi secara lebih dalam untuk memperoleh masalah dan solusi dari permasalahan wakaf yang sebenarnya. 
2 Kuantifikasi Model

Tahap kuantifikasi model menggunakan pertanyaan dalam kuesioner ANP berupa pairwise comparison (pembandingan berpasangan) antarelemen dalam cluster untuk mengetahui besar prioritas di antara keduanya mana yang lebih besar pengaruhnya dan seberapa besar perbedaannya melalui skala numerik 1-9 seperti pada Tabel 1.

Tabel 1 Perbandingan skala verbal dan skala numerik

\begin{tabular}{cc}
\hline Skala Numerik & Skala Verbal \\
\hline 1 & Sama besar \\
2 & Antara sama besar sampai sedang \\
3 & Sedang \\
4 & Antara sedang sampai kuat \\
5 & Kuat \\
6 & Antara kuat sampai sangat kuat \\
7 & Sangat kuat \\
8 & Antara sangat kuat sampai amat sangat kuat \\
9 & Amat sangat kuat \\
\hline
\end{tabular}

Sumber : Ascarya (2005)

3 Sintesis dan Analisis

Data hasil penilaian dalam kuesioner yang telah diisi oleh responden kemudian dikumpulkan dan diinput melalui software SuperDecision untuk diproses sehingga menghasilkan output berbentuk prioritas dan supermatriks. Kemudian data dari software SuperDecision dicari nilai geometric mean (GMk) dan menghitung nilai Kendall's coefficient of concordance yang merupakan alat untuk menghitung rater agreement dengan menggunakan Microsoft Excel.

a. Geometric mean

Untuk mengetahui hasil penilaian dari para pakar dan menentukan hasil pendapat pada satu kelompok dilakukan penilaian dengan menghitung geometric mean. Pertanyaan berupa perbandingan (pairwise comparasion) dari para pakar akan dikombinasikan sehingga membentuk suatu konsesnsus. Geometric mean adalah jenis penghitungan rata-rata yang menunjukkan tendensi atau nilai tertentu dimana memiliki formula sebagai berikut:

$$
\left(\prod_{n}^{1}=1 a_{1}\right)^{\frac{1}{n}}=\sqrt[n]{a_{1} a_{2 \ldots} a_{n}}
$$

b. Rater Agreement

Rater agreement adalah ukuran yang menunjukkan tingkat kesesuaian (persetujuan) para responden terhadap satu masalah dalam satu cluster (Rusydiana \& Devi, 2013). Adapun alat yang digunakan untuk mengukur rater agreement adalah Kendall's coefficient of concordance (W;0< $\mathrm{W} \leq$ ). $\mathrm{W}=1$ menunjukkan kesesuaian yang sempurna, sedangkan nilai $\mathrm{W}$ sebesar 0 atau semakin mendekati 0 menunjukkan adanya ketidaksesuaian antar jawaban responden atau jawaban bervariatif (Ascarya, 2011). Tahapan dalam menghitung rater agreement adalah data di-transpose, kemudian diurukan berdasarkan ranking dan dihitung nilai $\mathrm{W}$.

\section{HASIL DAN PEMBAHASAN}

\section{Gambaran Umum Wakaf di Kabupaten Banjarnegara}

Kabupaten Banjarnegara merupakan salah satu kabupaten dari 35 kabupaten di Provinsi Jawa Tengah. Kabupaten Banjarnegara memiliki luas wilayah 106971 hektar yang terletak di antara $7^{\circ} 12^{\prime}-7^{\circ} 31^{\prime}$ Lintang Selatan dan $109^{\circ} 29^{\prime}-109^{\circ} 45^{\prime} 50^{\prime \prime}$ Bujur Timur. Kabupaten ini berbatasan dengan Kabupaten Pekalongan dan Kabupaten Batang di Utara, Kabupaten Wonosobo di Timur, Kabupaten Kebumen di Selatan, dan Kabupaten Banyumas dan Kabupaten Purbalingga di sebelah Barat (Pemkab Banjarnegara, 2013). Kebanyakan masyarakat di kabupaten bekerja sebagai petani. 
Kabupaten Banjarnegara memiliki potensi untuk mengembangkan wakaf produktif. Jumlah penduduk mayoritas beragama Islam dan juga memiliki aset tanah wakaf yang cukup luas, yaitu 90.27 hektar dengan jumlah 3219 lokasi. Jumlah yang sudah bersertifikat mencapai 2268 lokasi seluas 51.81 hektar atau sekitar 70.1\% dari jumlah wakaf terdaftar (SIWAK, 2018). Kebanyakan dari aset wakaf tersebut belum dikelola secara produktif. Hal tersebut dapat dilihat dari Gambar 3 bahwa jumlah lokasi tanah wakaf terdiri dari 3723 lokasi dengan luas 90.27 hektar, dari jumlah tersebut yang produktif hanya 12 lokasi seluas 45808 meter persegi atau sebesar $0.30 \%$ saja. Sedangkan yang sudah bersertifikat sejumlah 3347 dan yang belum bersertifikat sejumlah 357 lokasi. Informasi dari kantor pertanahan kabupaten yang belum jadi masih 19 lokasi.

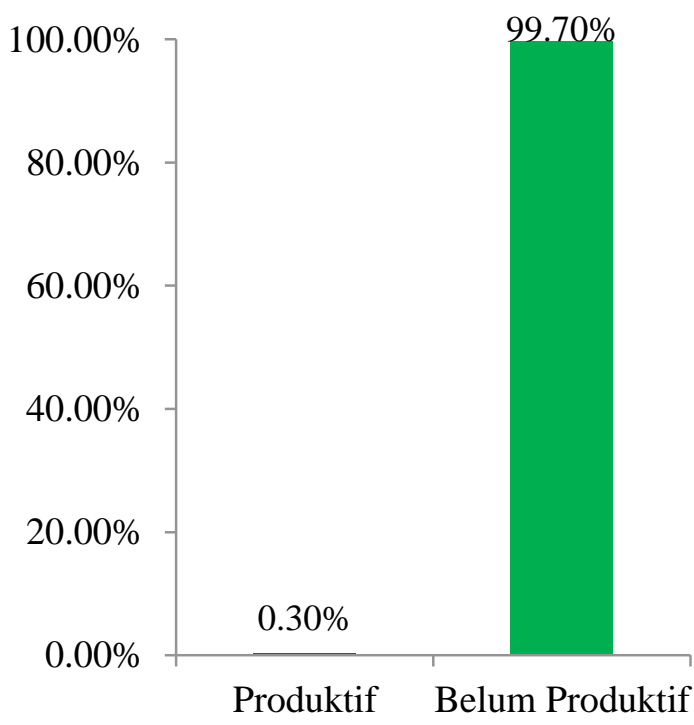

Sumber: Kementerian Agama Kabupaten Banjarnegara (diolah)

Gambar 3 Perbandingan alokasi tanah wakaf produktif dan non produktif tahun 2015

Kebanyakan aset tanah wakaf di Banjarnegara diperuntukan untuk masjid, mushalla, madrasah, pondok pesantren, dan kuburan. Sebagian kecil sudah ada yang diperuntukan untuk kegiatan produktif, seperti untuk mendirikan ruko yang disewakan yang dikelola oleh organisasi Islam Muhammadiyah, sebagian yang lain ada yang digunakan untuk kegiatan pertanian dan perikanan. Menurut salah satu pakar mengatakan bahwa mayoritas masyarakat Kabupaten Banjarnegara memiliki pemahaman tentang wakaf yang masih tradisional, yaitu wakaf hanya untuk masjid, mushalla, pondok pesantren, dan kuburan saja, belum ke arah wakaf produktif. Padahal wakaf juga dapat diperuntukan untuk kegiatan yang produktif. Hal inilah salah satu penyebab kebanyakan wakaf di Kabupaten Banjarnegara diperuntukan untuk wakaf langsung.

Badan Wakaf Indonesia (BWI) adalah lembaga independen untuk mengembangkan perwakafan di Indonesia. BWI dibentuk berdasarkan Undang-Undang Nomor 41 Tahun 2004 tentang Wakaf dan berkedudukan di Ibukota Negara. Dalam rangka mendukung pelaksanaan tugas dan fungsinya, BWI membentuk perwakilan BWI provinsi untuk tingkat provinsi dan perwakilan BWI kabupaten/kota untuk daerah tingkat dua. Perwakilan BWI provinsi berkedudukan di ibukota provinsi dan mempunyai hubungan hierarkis dengan BWI. Sementara itu, perwakilan BWI kabupaten/kota berkedudukan di ibukota kabupaten/kota dan mempunyai hubungan hierarkis dengan perwakilan BWI provinsi. Kabupaten Banjarnegara pada 3 Agustus 2015 telah resmi mendirikan BWI perwakilan kabupaten yang beranggotakan sembilan orang. Dengan didirikannya BWI perwakilan ini, diharapkan mampu mengoptimalkan aset-aset wakaf yang ada di Kabupaten Banjarnegara. Namun, sampai saat ini BWI perwakilan Kabupaten Banjarnegara belum bekerja secara efektif dikarenakan permasalahan pendanaan. 


\section{Permasalahan}

Berdasarkan hasil kajian literatur dan wawancara secara mendalam dengan para pakar dan praktisi di bidang wakaf di Kabupaten Banjarengara, maka dapat dikumpulkan masalah yang menyebabkan pengelolaan tanah wakaf belum produktif menjadi tiga kelompok, yaitu masalah sumber daya manusia, masalah kelembagaan, dan masalah pemerintah. Masalah sumber daya manusia terbagi menjadi tiga aspek, yaitu pemahaman masyarakat masih tradisional, nazhir kurang kreatif, dan kemampuan manajerial nazhir masih rendah. Masalah kelembagaan terbagi menjadi dua aspek, yaitu peran BWI Kabupaten Banjarnegara belum optimal dan rendahnya koordinasi dengan lembaga terkait. Masalah pemerintah terbagi menjadi tiga aspek, yaitu kurangnya bantuan fasilitas dan dana, legalisasi tanah wakaf, dan kurangnya dukungan dan peran pemerintah.

Berdasarkan hasil pengolahan data, prioritas utama masalah yang menyebabkan pengelolaan wakaf di Kabupaten Banjarnegara belum produktif adalah masalah sumber daya manusia dengan nilai geometric mean (GMk) sebesar 0.38, sedangkan prioritas kedua adalah masalah kelembagaan dengan nilai GMk sebesar 0.31. Masalah yang menjadi prioritas terakhir adalah masalah pemerintah dengan nilai GMk sebesar 0.30. Tingkat prioritas tersebut bisa dilihat dengan jelas dalam Gambar 4.

Dari data tersebut menunjukkan bahwa masalah yang paling besar memengaruhi pengelolaan wakaf di Kabupaten Banjarnegara adalah masalah sumber daya manusia, sehingga masalah sumber daya manusia perlu mendapatkan perhatian yang lebih besar dari masalah yang lainnya. Menurut salah satu pakar mengatakan bahwa sumber daya manusia merupakan faktor yang paling penting dalam mengembangkan wakaf produktif. Hal ini sama dengan penelitian yang dilakukan oleh Hamzah (2016). Perhitungan rater agreement menghasilkan nilai Kendall's coefficient of concordance atau nilai W sebesar 0.36, hal ini menunjukkan bahwa tingkat kesepakatan para pakar terhadap persoalaan pengelolaan wakaf cenderung bervariatif.

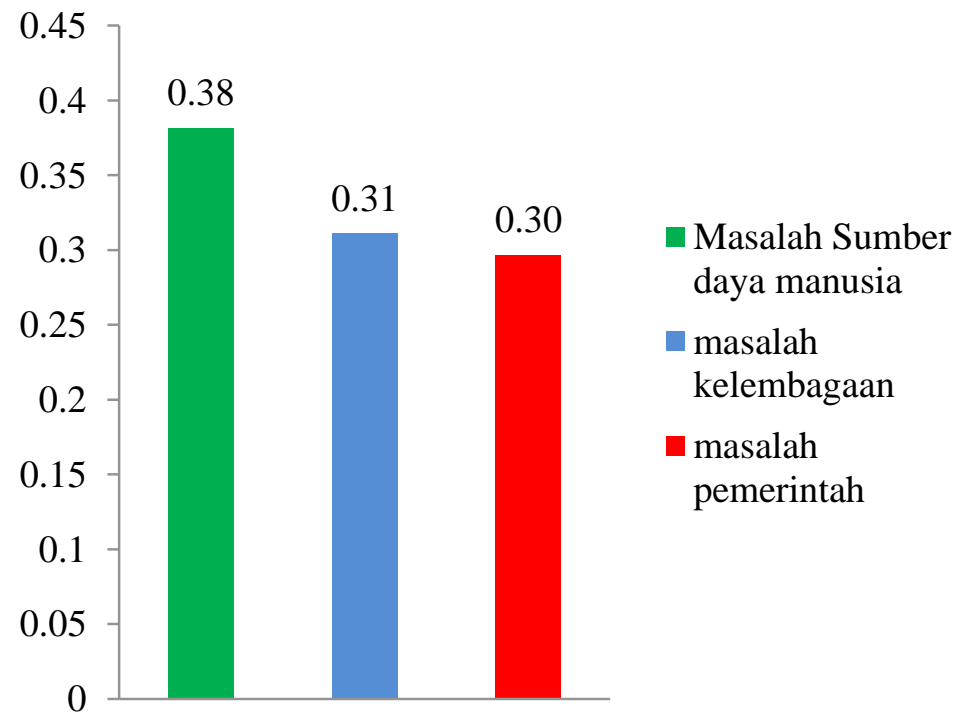

Gambar 4 Tingkat prioritas masalah pengelolaan wakaf di Kabupaten Banjarnegara

\section{Masalah sumber daya manusia}

Sumber daya manusia yang dimaksud di sini adalah wakif, nazhir, dan para pelaku yang terkait dengan wakaf yang lain. Sumber daya manusia memiliki peranan yang sangat penting dalam mengembangkan wakaf karena sebagai pelaku pengembang wakaf. Hasil dari pengolahan data dapat dilihat pada Gambar 5 yang menunjukkan bahwa prioritas utama pada aspek masalah sumber daya manusia adalah kemampuan manajerial nazhir masih rendah dengan nilai geometric mean (GMk) sebesar 0.34. Prioritas masalah kedua dalam aspek sumber daya manusia adalah masalah nazhir kurang kreatif dengan nilai GMk sebesar 0.34. Prioritas masalah ketiga adalah pemahaman 
masyarakat masih tradisional dengan nilai GMk sebesar 0.31. Perhitungan rater agreement menghasilkan nilai Kendall's coefficient of concordance atau nilai W sebesar 0.28. Hal ini menunjukkan bahwa tingkat kesepakatan para pakar wakaf terhadap masalah yang menyebabkan wakaf belum berkembang pada aspek sumber daya manusia bervariasi.

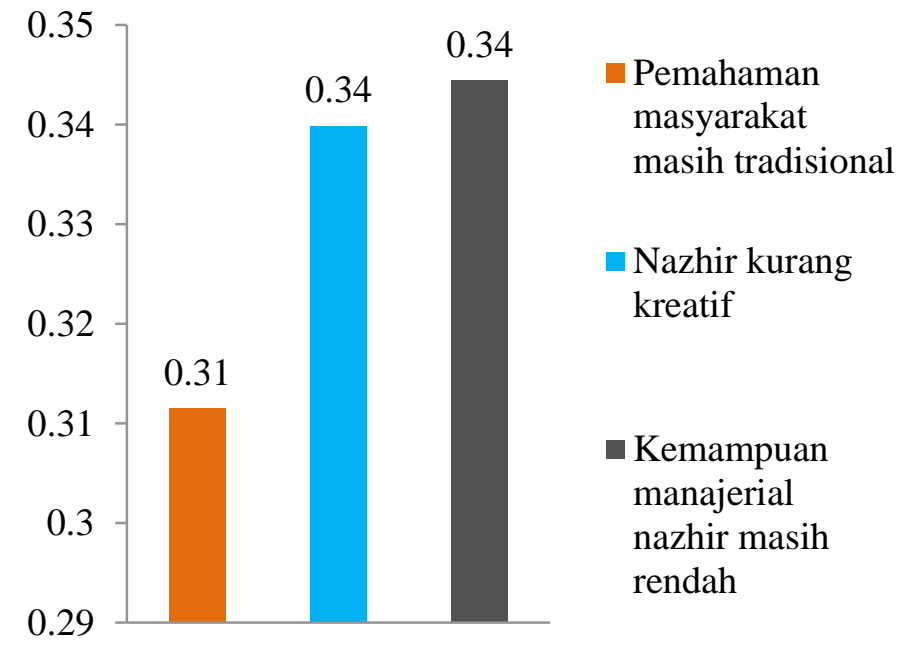

Gambar 5 Prioritas masalah pada aspek sumber daya manusia

Prioritas utama adalah kemampuan manajerial nazhir masih rendah. Menurut Hasan (2011) nazhir mempunyai posisi dan fungsi yang strategis dalam pengelolaan dan pengembangan wakaf, kapan saja dan di mana saja. Tugas dan kewajiban nazhir adalah melakukan segala hal yang berkaitan dengan perlindungan terhadap barang wakaf, penjagaan kemaslahatannya, dan pengembangan kemanfaatannya. Akan tetapi saat ini kondisi nazhir di Kabupaten Banjarnegara banyak yang belum memiliki kemampuan manajerial yang baik sebagaimana yang disampaikan oleh salah seorang pakar. Hamzah (2016) mengatakan bahwa dalam pengelolaan wakaf diperlukan kemampuan manajerial yang baik agar kegiatan pengelolaan wakaf dapat berjalan secara efektif dan efisien. Menurut Rozalinda (2016), manajemen wakaf yang ideal adalah manajemen yang menyerupai dengan manajemen perusahaan, sedangkan peran kunci dalam pengelolaan wakaf terletak pada eksistensi nazhir. Dengan demikian dalam pengembangan wakaf produktif diperlukan nazhir yang memiliki kemampuan manajerial yang baik, nazhir yang berbentuk badan hukum dan organisasi biasanya memiliki kemampuan manajerial yang lebih baik dibandingkan dengan nazhir individu.

\section{Masalah kelembagaan}

Lembaga wakaf muncul bersamaan dengan lahirnya masyarakat muslim sebagai sebuah komunitas keagamaan yang umumnya memerlukan fasilitas-fasilitas peribadahan dan pendidikan untuk menjamin kelangsungannya seperti masjid, mushalla, dan pesantren (Huda, 2013). Pada masa kini lembaga-lembaga wakaf muncul juga dikarenakan untuk mengelola harta wakaf agar produktif. Kelembagaan yang dimaksud di sini adalah lembaga yang berkaitan tentang wakaf, seperti BWI, lembaga nazhir, KUA, dan lembaga lain yang terkait dengan wakaf.

Hasil dari pengolahan data dapat dilihat pada Gambar 6 yang menunjukkan bahwa prioritas utama pada aspek masalah kelembagaan adalah peran BWI Kabupaten Banjarnegara belum optimal dengan nilai geometric mean (GMk) sebesar 0.51. Prioritas masalah kedua dalam aspek kelembagaan adalah masalah rendahnya koordinasi dengan lembaga terkait dengan nilai GMk sebesar 0.48. Perhitungan rater agreement menghasilkan nilai Kendall's coefficient of concordance atau nilai W sebesar 0.04 . Hal ini menunjukkan bahwa tingkat kesepakatan para pakar dan praktisi wakaf terhadap masalah yang menyebabkan wakaf belum berkembang pada aspek kelembagaan sangat bervariatif. 


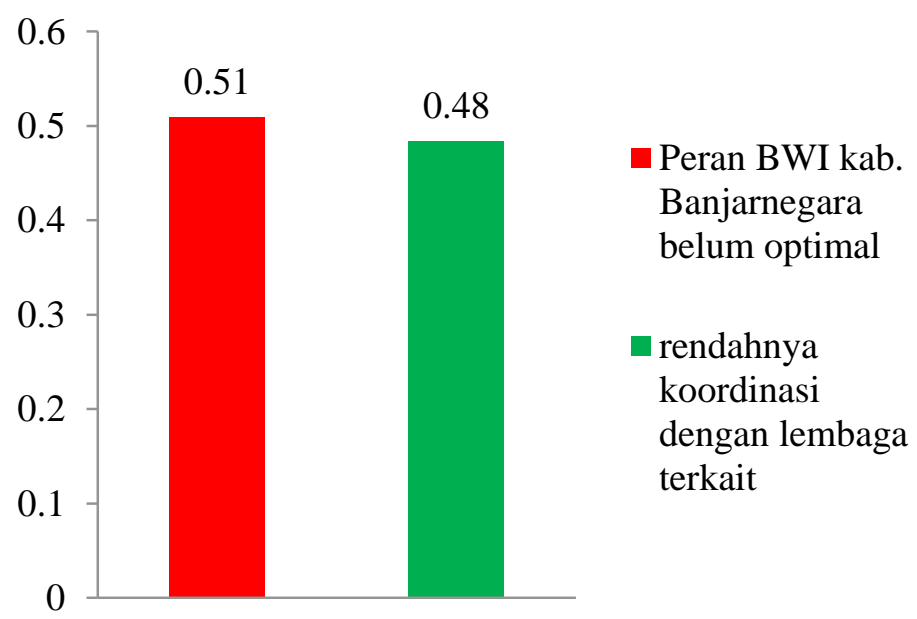

Gambar 6 Prioritas masalah kelembagaan

Prioritas utama adalah peran BWI Kabupaten Banjarnegara belum optimal. BWI adalah lembaga independen yang didirikan untuk mengembangkan perwakafan di Indonesia (UU Nomor 41 Tahun 2004). Dalam pasal 49 ayat 1 Undang-Undang Nomor 41 Tahun 2004 tentang Wakaf, BWI mempunyai tugas dan wewenang sebagai berikut: (1) melakukan pembinaan terhadap nazhir dalam mengelola dan mengembangkan harta benda wakaf, (2) melakukan pengelolaan dan pengembangan harta benda wakaf berskala nasional dan internasional, (3) memberikan persetujuan dan/atau izin atas perubahan peruntukan dan status harta benda wakaf, (4) memberhentikan dan mengganti nazhir, (5) memberikan persetujuan atas penukaran harta benda wakaf, dan (6) memberikan saran dan pertimbangan kepada pemerintah dalam penyusunan kebijakan di bidang perwakafan. Hal tersebut menunjukkan bahwa BWI mempunyai peranan yang sangat strategis dalam membantu meningkatkan produktivitas harta benda wakaf, baik dalam pembiayaan, pembinaan, maupun pengawasan terhadap nazhir wakaf agar dapat melakukan pengelolaan wakaf secara produktif dan profesional (Nasution, 2008). BWI perwakilan Kabupaten Banjarnegara sudah dibentuk sejak tahun 2015. BWI sudah hampir tiga tahun berdiri akan tetapi peranannya masih sangat kurang. Kurangnya peranan BWI Kabupaten Banjarnegara disebabkan oleh pendanaan yang minim dan sumber daya manusia yang masih terbatas.

\section{Masalah pemerintah}

Pemerintah adalah perangkat Negara Kesatuan Republik Indonesia yang terdiri atas Presiden dan para menteri. Lembaga pemerintah yang membawahi urusan wakaf di Kabupaten Banjarnegara adalah Kantor Kementerian Agama Kabupaten Banjarnegara bagian syariah. Hasil dari pengolahan data dapat dilihat pada Gambar 7 yang menunjukkan bahwa prioritas utama pada aspek masalah pemerintah adalah kurangnya dukungan dan peran pemerintah dengan nilai geometric mean (GMk) sebesar 0.37 .

Prioritas masalah kedua dalam aspek pemerintah adalah masalah kurangnya bantuan fasilitas dan dana dengan nilai GMk sebesar 0.33. Prioritas masalah ketiga adalah legalisasi tanah wakaf dengan nilai GMk sebesar 0.30. Perhitungan rater agreement menghasilkan nilai Kendall's coefficient of concordance atau nilai W sebesar 0.64. Hal ini menunjukkan bahwa tingkat kesepakatan para pakar wakaf terhadap masalah yang menyebabkan wakaf belum berkembang pada aspek pemerintah cukup tinggi. 


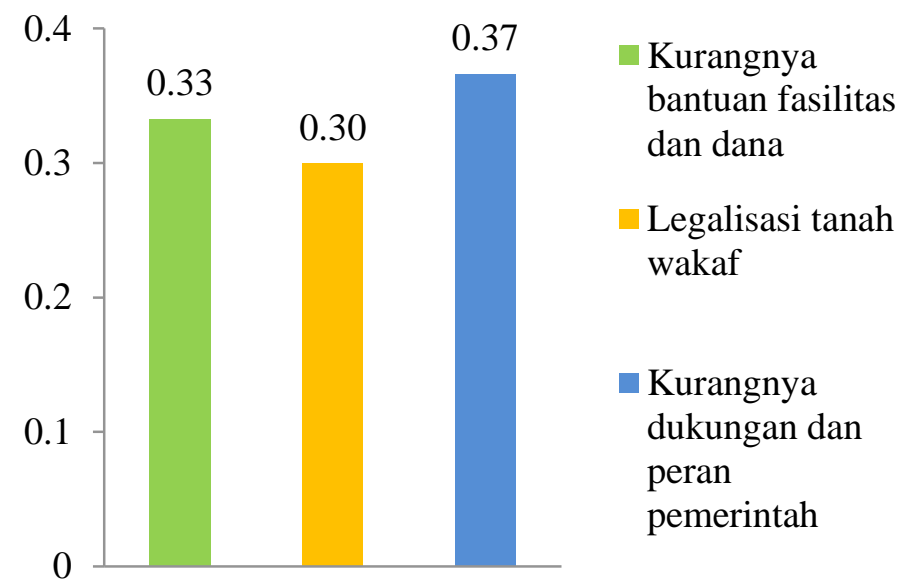

Gambar 7 Prioritas masalah pemerintah

Prioritas utama yang menyebabkan wakaf belum berkembang pada aspek pemerintah adalah kurangnya dukungan dan peran pemerintah dengan nilai GMk sebesar 0.37. Menurut salah satu pendapat pakar mengatakan bahwa perhatian pemerintah Kabupaten Banjarnegara terhadap wakaf masih sangat kurang. Hal tersebut dapat dilihat dari kurangnya pengawasan pemerintah dan juga bantuan berupa fasilitas dan dana. Hal ini dikarenakan wakaf masih dipandang sebelah mata oleh pemerintah. Padahal kalau dicermati pemerintah sangat terbantu dengan adanya instrumen wakaf dikarenakan pemerintah tidak perlu mengeluarkan dana untuk pembuatan rumah ibadah, madrasah, kuburan, dan pondok pesantren. Bisa dibayangkan berapa besar dana yang harus dikeluarkan oleh pemerintah jika tidak ada instrumen wakaf.

Sudah seharusnya pemerintah menyadari akan pentingnya wakaf dalam pembangunan ekonomi dan memberikan perhatian yang lebih terhadap wakaf ini. Yuliani (2017) mengatakan bahwa perkembangan wakaf di Arab Saudi sangat berkembang karena mendapatkan dukungan penuh dari pemerintah, bahkan ada kementerian khusus yang menangani masalah wakaf. Hal tersebut menunjukkan bahwa dukungan dan pemerintah sangat diperlukan dalam mengembangkan wakaf produktif.

\section{Solusi}

Berdasarkan hasil kajian literatur dan wawancara secara mendalam dengan para pakar di bidang wakaf di Kabupaten Banjarnegara maka dapat dikumpulkan solusi dari permasalahan wakaf yang terbagi menjadi tiga kelompok, yaitu solusi sumber daya manusia, solusi kelembagaan, dan solusi pemerintah. Berdasarkan hasil pengolahan data, prioritas utama solusi untuk meningkatkan pengelolaan wakaf secara produktif di Kabupaten Banjarnegara adalah solusi sumber daya manusia dengan nilai geometric mean (GMk) sebesar 0.37, sedangkan prioritas kedua adalah solusi pemerintah dengan nilai GMk sebesar 0.309. Solusi yang menjadi prioritas terakhir adalah solusi kelembagaan dengan nilai GMk sebesar 0.307. Tingkat prioritas tersebut bisa dilihat dalam Gambar 8.

Dari data tersebut menunjukkan bahwa solusi yang paling utama adalah solusi sumber daya manusia, sehingga sumber daya manusia perlu mendapatkan perhatian yang lebih besar dari solusi yang lain. Hal ini hampir sama dengan penelitian yang dilakukan oleh Yuliani (2017) mengenai strategi optimalisasi pengelolaan wakaf di Indonesia yang menunjukkan faktor internal yang di dalamnya mencakup sumber daya nazhir memiliki prioritas solusi utama. Perhitungan rater agreement menghasilkan nilai Kendall's coefficient of concordance atau nilai $\mathrm{W}$ sebesar 0.36 , hal ini menunjukkan bahwa tingkat kesepakatan para pakar terhadap persoalaan pengelolaan wakaf cenderung bervariatif. 


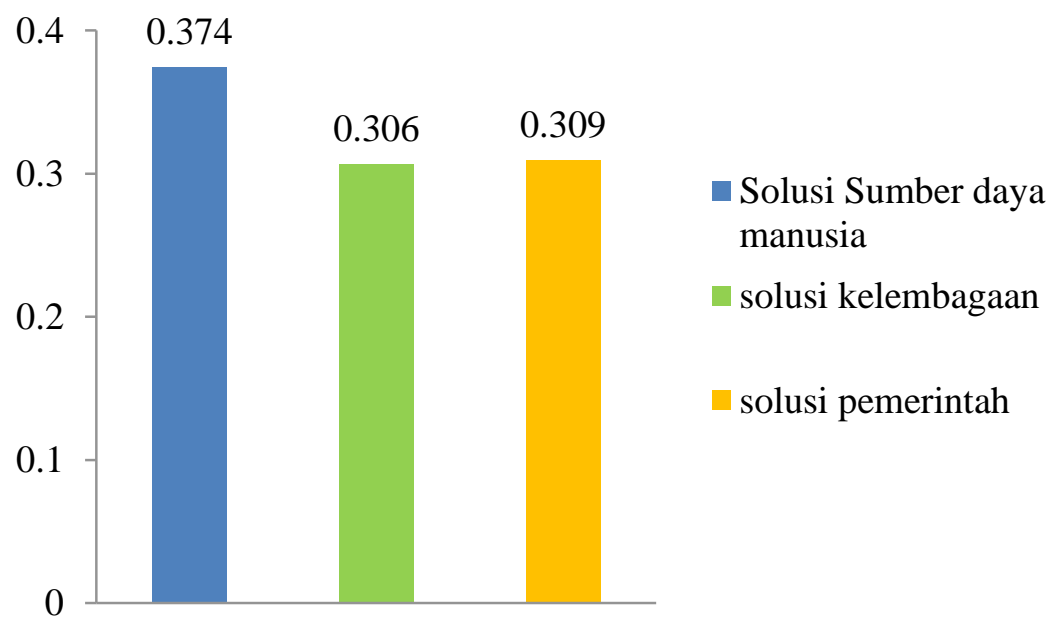

Gambar 8 Prioritas solusi permasalahan aset wakaf di Kabupaten Banjarnegara

\section{Solusi sumber daya manusia}

Solusi sumber daya manusia yang dimaksud di sini adalah solusi yang dapat diberikan untuk mengatasi masalah sumber daya manusia yang telah dipaparkan sebelumnya. Hasil dari pengolahan data dapat dilihat pada Gambar 9 yang menunjukkan bahwa prioritas utama pada aspek solusi sumber daya manusia adalah pembinaan dan pendampingan nazhir dengan nilai geometric mean (GMk) sebesar 0.30. Prioritas solusi kedua dalam aspek sumber daya manusia adalah sosialisasi dan edukasi kepada masyarakat dengan nilai GMk sebesar 0.28. Prioritas solusi yang ketiga adalah perbaikan ikrar wakaf yang lebih longgar dengan nilai GMk sebesar 0.22. Prioritas solusi yang terakhir adalah studi banding ke nazhir yang berhasil dengan nilai GMk sebesar 0.21 . Perhitungan rater agreement menghasilkan nilai Kendall's coefficient of concordance atau nilai W sebesar 0.728. Hal ini menunjukkan bahwa tingkat kesepakatan para pakar wakaf terhadap solusi permasalahan wakaf produktif pada aspek sumber daya manusia cukup tinggi.

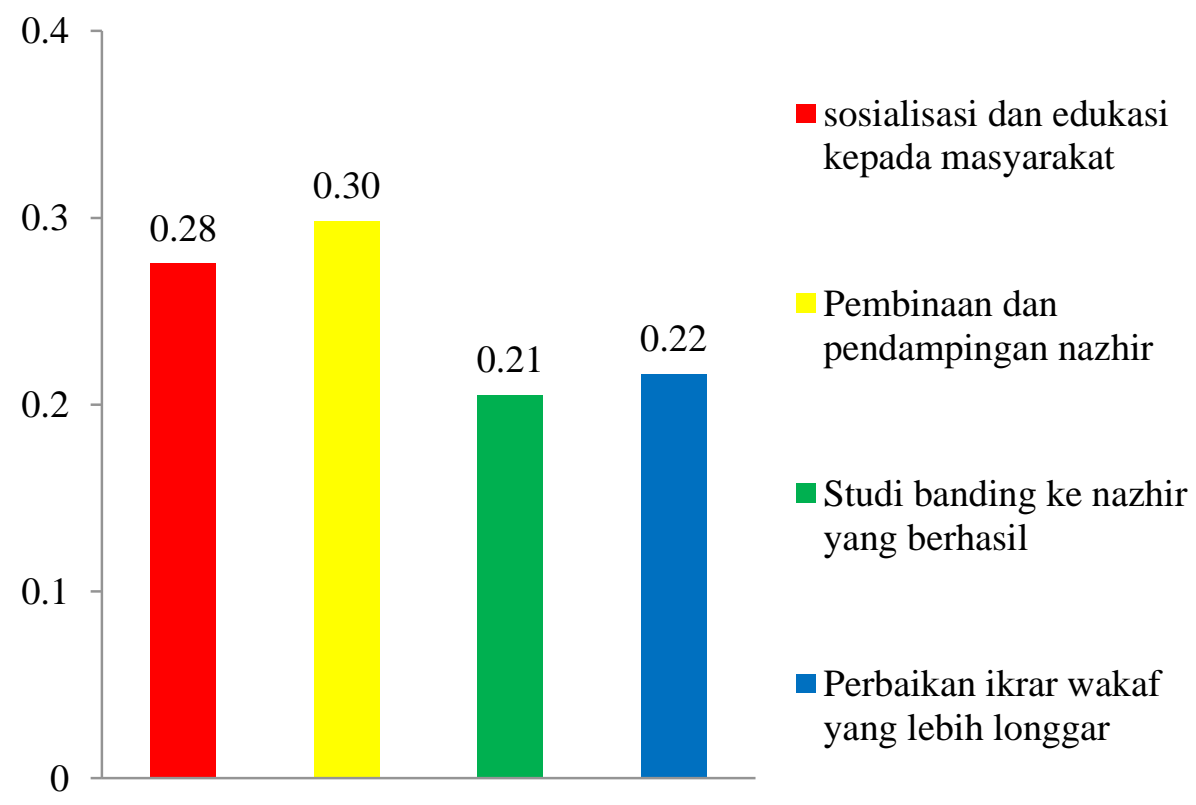

Gambar 9 Prioritas solusi sumber daya manusia

Prioritas utama pada aspek solusi sumber daya manusia adalah pembinaan dan pendampingan nazhir dengan nilai GMk sebesar 0.30. Solusi ini sangat penting mengingat masalah manajemen nazhir dan tingkat kreativitas nazhir di Kabupaten Banjarnegara masih rendah. Nazhir memiliki tugas dan 
kewajiban yang cukup berat, namun perhatian terhadap kompetensi nazhir masih kurang. Berdasarkan PP Nomor 42 Tahun 2006 pada pasal 53 menyatakan bahwa nazhir berhak memperoleh pembinaan dari menteri dan BWI. Dengan adanya pembinaan dan pendampingan nazhir yang intensif diharapkan mampu meningkatkan kreativitas dan manajerial para nazhir sehingga dapat mengelola harta benda wakaf dengan baik. Kendala yang dihadapi dalam pembinaan dan pengawasan nazhir di Kabupaten Banjarnegara adalah kendala pendanaan yang masih minim untuk melakukan kegiatan pelatihan dan pengawasan.

\section{Solusi pemerintah}

Solusi pemerintah yang dimaksud di sini adalah solusi yang dapat diberikan untuk mengatasi masalah pemerintah yang telah dipaparkan sebelumnya. Hasil dari pengolahan data dapat dilihat pada Gambar 10 yang menunjukkan bahwa prioritas utama pada aspek solusi pemerintah adalah membebaskan biaya sertifikasi tanah wakaf dengan nilai geometric mean (GMk) sebesar 0.28. Prioritas solusi kedua dalam aspek pemerintah adalah meningkatkan dukungan dan peran pemerintah dengan nilai GMk sebesar 0.25. Prioritas solusi yang ketiga adalah penambahan alokasi dana APBN dengan nilai GMk sebesar 0.23. Prioritas solusi yang terakhir adalah penggunaan dana APBD untuk tiap wilayah dengan nilai GMk sebesar 0.22. Perhitungan rater agreement menghasilkan nilai Kendall's coefficient of concordance atau nilai W sebesar 0.168. Hal ini menunjukkan bahwa tingkat kesepakatan para pakar wakaf terhadap solusi permasalahan wakaf produktif pada aspek solusi pemerintah cukup bervariasi.

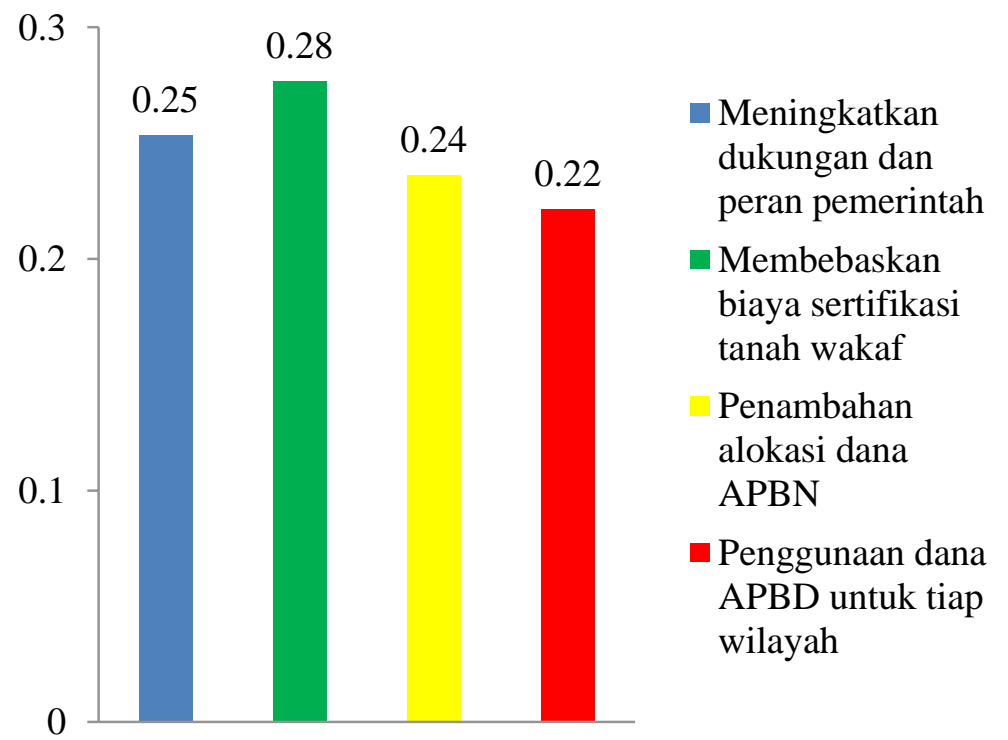

Gambar 10 Proritas solusi pemerintah

Prioritas utama pada aspek solusi pemerintah adalah membebaskan biaya sertifikasi tanah wakaf dengan nilai GMk sebesar 0.28. Legalisasi tanah wakaf memengaruhi investasi terhadap tanah wakaf, apabila tanah wakaf tidak memiliki legalisasi secara hukum dapat menimbulkan kurangnya minat investor untuk menanamkan modalnya terhadap aset-aset wakaf karena berisiko tinggi. Kendala dalam nazhir melakukan sertifikasi tanah wakaf adalah karena biaya dalam mengurus sertifikasi cukup mahal dan tidak terjangkau, hal ini dikatakan sendiri oleh responden dari pihak nazhir, sehingga para nazhir banyak yang tidak melakukan sertifikasi tanah wakaf yang dikelolanya. Dengan membebaskan biaya sertifikasi tanah wakaf yang sebenarnya dapat dilakukan oleh pemerintah dapat mendorong nazhir untuk melakukan sertifikasi tanah wakaf, hal tersebut dapat meningkatkan minat investor untuk berinvestasi sehingga wakaf produktif dapat berkembang.

\section{Solusi kelembagaan}

Solusi kelembagaan yang dimaksud di sini adalah solusi yang dapat diberikan untuk mengatasi masalah kelembagaan yang telah dipaparkan sebelumnya. Hasil dari pengolahan data dapat dilihat 
pada Gambar 11 yang menunjukkan bahwa prioritas utama pada aspek solusi kelembagaan adalah meningkatkan koordinasi dengan lembaga terkait lain dengan nilai geometric mean (GMk) sebesar 0.255. Kelembagaan yang dimaksud adalah lembaga yang terkait dengan wakaf, selain BWI, LAZ, dan BAZ dan lembaga wakaf yang dimiliki ormas Islam. Lembaga tersebut misalnya adalah lembaga bisnis, dukungan dari lembaga bisnis memang sangat dibutuhkan untuk menjalin kemitraan dalam rangka menggerakan seluruh potensi ekonomi yang dimiliki oleh aset wakaf. Menurut seorang pakar mengatakan bahwa dibutuhkan nazhir yang memiliki jiwa wirausaha dan memiliki jaringan bisnis yang luas, karena kebanyakan dari nazhir yang ada bukan orang yang tepat untuk mengembangkan ekonomi. Sehingga dibutuhkan adanya koordinasi dengan lembaga terkait lain dengan harapan mampu bekerja sama yang saling menguntungkan.

Prioritas solusi kedua dalam aspek solusi kelembagaan adalah optimalisasi peran dan fungsi BWI dengan nilai GMk sebesar 0.250. Prioritas solusi yang ketiga adalah melakukan sinergi dengan BAZ dan LAZ dengan nilai GMk sebesar 0.249. Prioritas solusi yang terakhir adalah koordinasi dengan ormas Islam dengan nilai GMk sebesar 0.225. Perhitungan rater agreement menghasilkan nilai Kendall's coefficient of concordance atau nilai W sebesar 0.188. Hal ini menunjukkan bahwa tingkat kesepakatan para pakar wakaf terhadap solusi permasalahan wakaf produktif pada aspek solusi pemerintah cukup bervariatif.

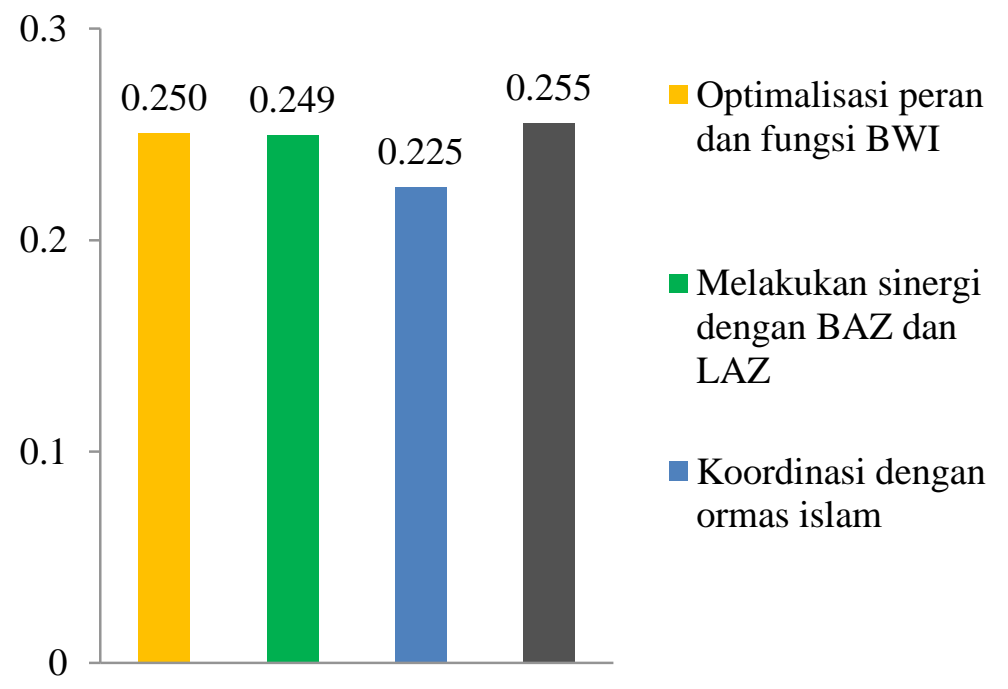

Gambar 11 Prioritas solusi kelembagaan

\section{IMPLIKASI TERHADAP PERKEMBANGAN EKONOMI ISLAM DAN PENINGKATAN KESEJAHTERAAN MASYARAKAT}

Wakaf merupakan salah satu Islamic social finance yang berperan penting dalam meningkatkan kesejahteraan masyarakat dan mengentaskan kemiskinan. Hasil penelitian ini berkontribusi terhadap perkembangan ekonomi Islam serta sebagai masukan bagi pengambil kebijakan, baik di tingkat pusat dan daerah dalam meningkatkan kesejahteraan masyarakat.

Tujuan ekonomi Islam adalah sebagaimana tujuan dari syariah Islam itu sendiri (maqashid asy syariah), yaitu mencapai kebahagiaan di dunia dan akhirat (falah) melalui tata kehidupan yang baik dan terhormat. Dengan berkembangnya keuangan sosial Islam seperti wakaf dan zakat maka sistem ekonomi Islam akan semakin mudah mencapai tujuannya. Di Indonesia, perkembangan ekonomi Islam semakin meningkat dewasa ini, khususnya terkait social finance ini. Lembaga zakat yang sudah lebih dahulu berkembang, sudah mencapai ke tingkat pelosok Indonesia, dan telah berkontribusi terhadap perekonomian dan kesejahteraan masyarakat. Saatnya lembaga wakaf juga mulai 
direvitalisasi dan ikut berkontribusi terhadap perkembangan ekonomi Islam dan menjadikan ekonomi Islam nantinya sebagai mainstream dalam perekonomian Indonesia.

Dalam hal peningkatan kesejahteraan masyarakat, wakaf telah terbukti berhasil mendukung kegiatan ekonomi pemerintahan sejak zaman Khulafaurrasyidin hingga ke zaman Ottoman Turki. Fakta tersebut yang mendorong pemerintahan di negara-negara muslim sekarang mengkaji ulang dan merevitalisasi peran dan fungsi lembaga wakaf. Usaha revitalisasi lembaga wakaf bertujuan untuk menjadikan wakaf sebagai salah satu instrumen penting dalam rangka menciptakan maslahah atau masyarakat yang lebih baik.

Memproduktifkan potensi wakaf yang selama ini belum produktif seperti wakaf harta tidak bergerak merupakan langkah penting dalam rangka membantu pemerintah menggiatkan ekonomi masyarakat. Sebagai contoh kasus di Banjarnegara dimana sekitar 99\% wakaf harta belum dikelola dengan baik. Permasalahan-permasalahan yang sudah diidentifikasi pada penelitian ini serta ditemukan prioritasprioritas solusi dari permasalahan tersebut akan membantu pemerintah daerah, khususnya lembaga yang mengelola wakaf dalam merencanakan pengembangan potensi wakaf harta ke depannya.

\section{SIMPULAN DAN SARAN}

\section{Simpulan}

Masalah yang menyebabkan pengelolaan wakaf di Kabupaten Banjarnegara belum optimal terbagi menjadi tiga, yaitu masalah sumber daya manusia, masalah kelembagaan, dan masalah pemerintah. Aspek masalah sumber daya manusia memiliki pengaruh paling besar dibandingkan dengan aspek yang lain. Hasil prioritas dari masing-masing aspek menunjukkan bahwa tiga masalah yang paling memengaruhi tingkat pengelolaan aset wakaf adalah kemampuan manajerial nazhir yang masih rendah, peran BWI Kabupaten Banjarnegara yang belum optimal, dan kurangnya dukungan dan peran pemerintah.

Solusi untuk meningkatkan pengelolaan wakaf produktif agar lebih optimal terbagi menjadi tiga aspek, yaitu solusi sumber daya manusia, solusi kelembagaan, dan solusi pemerintah. Aspek solusi sumber daya manusia memiliki pengaruh paling besar dibandingkan dengan aspek yang lain. Hasil prioritas dari masing-masing aspek menunjukkan bahwa tiga solusi yang paling memengaruhi tingkat pengelolaan aset wakaf adalah sosialisasi dan edukasi kepada masyarakat, meningkatkan koordinasi dengan lembaga terkait lain, dan membebaskan biaya sertifikasi tanah wakaf.

\section{Saran}

Berdasarkan simpulan dan hasil penelitian yang telah dilakukan, maka beberapa saran yang dapat diberikan dari penelitian ini adalah sebagai berikut:

1 Kemampuan manajerial dan kreativitas nazhir menjadi masalah utama bagi nazhir, sehingga butuh diberikan pelatihan dan pendampingan yang intensif dan berkelanjutan serta diawasi kinerjanya.

2 Peranan BWI saat ini masih belum optimal disebabkan karena minimnya pendanaan untuk melakukan tugasnya. Saat ini perlu penambahan pendanaan dari dana APBN dan/atau juga dapat menggunakan dana APBD untuk tiap wilayah sehingga BWI mampu bekerja lebih optimal.

3 Kerja sama antarlembaga diperlukan untuk meningkatkan efektivitas kinerja dalam mengembangkan wakaf produktif. Perlu adanya forum khusus yang di dalamnya tergabung berbagai macam elemen lembaga, baik dari pemerintah, BWI, nazhir, BAZ, ormas Islam, dan lembaga terkait yang lain sehingga dapat saling berkoordinasi dengan baik dan dapat saling bekerja sama.

4 Sosialisasi dan edukasi diperlukan untuk semua elemen, baik dari pemerintah, nazhir, maupun masyarakat luas yang umumnya masih memiliki pemahaman yang tradisional. Sosialisasi dapat dilakukan melalui ceramah-ceramah, khutbah Jumat, buletin-buletin, maupun melalui berbagai media sosial yang ada. 


\section{DAFTAR PUSTAKA}

Al-Mubarakfury, S. (2016) Syarah Bulughul Maram. Ahmad, Saikhu, A., Penerjemah; Haris, A., Amin, A., Editor. Surabaya, Pustaka eLBA. Terjemahan dari: Ithaaful Kiraam Syarh Bulughul al-maram Min Adillati Ahkaam. Riyadh, Darussalam cet. VI.

Ascarya. (2005) Analytic Network Process (ANP) Pendekatan Baru Studi Kualitatif. Jakarta, Seminar Internasional Program Magister Akuntansi Fakultas Ekonomi; 2005 Januari 27.

Ascarya. (2011) The persistance of low profit and loss sharing financing in Islamic banking. The case of Indonesia review of Indonesian economic and business studies. LIPI Economic Research Center 1 .

Ascarya \& Yumanita, D. (2011) Determinan dan persistensi margin perbankan konvensional dan syariah di Indonesia. Working Paper Series No. WP/10/04.

[BPS] Badan Pusat Statistik. (2018) Data Kemiskinan dan Angka Partisipasi Sekolah di Kabupaten Banjarnega [internet]. [diunduh pada 2018 April]. Tersedia pada https://jateng.bps.go.id/ (2018) Data Jumlah Penduduk dan Jumlah Kemiskinan Indonesia. [Internet]. [diunduh pada 2018 April]. Tersedia pada https://www.bps.go.id/

[BWI] Badan Wakaf Indonesia. (2017) Data Tanah Wakaf Seluruh Indonesia Juni 2017 [Internet]. [diunduh pada 2017 Juni 7]. Tersedia pada http://bwi.or.id/index.php/in/tentang-wakaf/datawakaf/data-wakaf-tanah.html

Djunaedi, A. \& Almuin, N. (2013) Peran Badan Wakaf Indonesia dalam Memproduktifkan Aset Wakaf Nasional [internet]. [diunduh 2017 Desember 2]. Tersedia pada https://bwi.or.id/index.php/in/publikasi/jurnal-al-awqaf/sekilas-jurnal-al-awqaf.html

Hamzah, Z. (2016) Analisis Faktor-faktor yang Memengaruhi Pengelolaan Wakaf di Kabupaten Bogor [skripsi]. Bogor, Institut Pertanian Bogor.

Hasan, T. (2011) Pemberdayaan Nazhir [internet]. [diunduh 2017 Desember 1]. Tersedia pada: https://bwi.or.id/index.php/in/publikasi/jurnal-al-awqaf/sekilas-jurnal-al-awqaf.html

Huda, M. (2013) Mekanisme Penciptaan Tatakelola Wakaf Kreatif di Indonesia [internet]. [diunduh 2017 Desember 1]. Tersedia pada: https://bwi.or.id/index.php/in/publikasi/jurnal-alawqaf/sekilas-jurnal-al-awqaf.html

Huda, N. (2015) Prioritas Solusi Permasalahan Waqaf di Provinsi Jawa Barat dengan Metode ANP [internet]. [diunduh 2017 Desember 1]. Tersedia pada: https://bwi.or.id/index.php/in/publikasi/jurnal-al-awqaf/sekilas-jurnal-al-awqaf.html

Khadijah. (2016) Analisis faktor-faktor yang memengaruhi penghimpunan wakaf uang di Indonesia (Pendekatan Analytical Network Process). Al-Muzara'ah, 4(2), 127-141.

[KEMENAG] Kementerian Agama RI. 2015. Data Tanah Wakaf Kabupaten Banjarnegara, Jawa Tengah. Banjarnegara, Kemenag.

Fokusindo Mandiri.

2016. Undang-Undang Kompilasi Hukum Islam. Bandung,

Nasution, M.E. (2008) Peran Badan Wakaf Indonesia (BWI) dalam Pengembangan Wakaf di Indonesia [internet]. [diunduh 2017 Desember 1]. Tersedia pada: https://bwi.or.id/index.php/in/publikasi/jurnal-al-awqaf/sekilas-jurnal-al-awqaf.html

Nurwati, N. (2008) Kemiskinan: Model pengukuran, permasalahan, dan alternatif kebijakan. Jurnal Kependudukan Padjadjaran, 10(1), 1-11

[Pemkab] Pemerintah Kabupaten Banjarnegara. (2013) Data Geografis Kabupaten Banjarnegara. Banjarnegara, Pemkab.

[PP] Peraturan Pemerintah Republik Indonesia Nomor 42 Tahun 2006 Tentang Pelaksanaan UndangUndang Republik Indonesia Nomor 41 Tahun 2004.

Rozalinda. (2016) Manajemen waqaf produktif di Sumatera Barat. [internet]. [diunduh 2017 Desember 1]. Tersedia pada: https://bwi.or.id/index.php/in/publikasi/jurnal-al-awqaf/sekilasjurnal-al-awqaf.html

Rusydiana, A.S. \& Devi, A. (2013) Analytic Network Process: Pengantar Teori dan Aplikasi. Bogor, SMART Publishing.

Sa'adah, N. \& Wahyudi, F. (2016) Manajemen wakaf produktif: Studi analisis pada baitul mal di Kabupaten Kudus. Equilibrium: Jurnal Ekonomi Syariah, 4(2), 334-352. 
Saifuddin, F.B., Kayadibi, S., Polat, R., Fidan, Y., \& Kayadibi, O. (2014) The role of cash waqf in poverty alleviation: Case of Malaysia. Dipresentasikan pada Seminar Waqf Iqlimi 2014, 28-42. Universiti Sains Islam Malaysia.

[SIWAK] Sistem Informasi Wakaf. (2018) Data Penggunaan Tanah Wakaf Indonesia [internet]. [diunduh 2018 April]. Tersedia pada: http://siwak.kemenag.go.id/index.php

Yuliani, M. (2017) Strategi Optimalisasi Pengelolaan Wakaf di Indonesia [skripsi]. Bogor, Institut Pertanian Bogor. 